\title{
Hubungan Keragaman Gen Insuline-like Growth Factor 2 (IGF2) terhadap Sifat Pertumbuhan pada Ayam Kampung
}

\section{Association of Insuine-Like Growth Factor 2 (IGF2) with Growth Traits in Kampung Chicken}

\author{
R.P. Rahmadani ${ }^{1}$, C. Sumantri², S. Darwati ${ }^{2}$, N.Ulupi ${ }^{2}$ \\ ${ }^{1}$ Fakultas Peternakan, Sekolah Pascasarjana, Institut Pertanian Bogor \\ ${ }^{2}$ Departemen Ilmu Produkdi dan Teknologi Peternakan, Fakultas Peternakan, Institut Pertanian Bogor, \\ J1. Agatis, Kampus IPB Dramaga, Bogor 16680, Indonesia \\ Correspondence author: ria.putri.rahmadani@gmail.com
}

\begin{abstract}
Kampung chicken is one of Indonesia native chickens which has slow growth and it needs to be improved. Growth is a quantitative trait which is controled by many genes. One of the genes which plays a crucial role in controling growth is IGF2 gene. The objective of this study was to analyze the association of IGF2 gene polymorphisms with growth traits in kampung chicken. A total of 56 male and female chicks were maintained for 16 weeks and genotyped using PCR-RFLP method.Result showed there was $\mathbf{T} \square \mathrm{C}$ muation on IGF2 gene and it was polymorphic in kampung chicken. Frequency of heterozigous TCwas the highest than the others. There was no association between IGF2 gene polymorphismswith growth traits in kampung chicken. It can be caused by the synonimus mutation on IGF2 sequence that does not alter the amino acid. Bot of the nucleotides coded for histidine. It may not give different effect toward the growth traits in kampung chicken.
\end{abstract}

Keywords: growth traits, IGF2 gene, kampung chicken, polymorphisms

\section{PENDAHULUAN}

Daging unggas memberikan konstribusi yang besar dalam memenuhi kebutuhan daging nasional yaitu sebesar $67.03 \%$ dengan kontribusi ayam ras pedaging yang paling dominan yaitu 52\%(BPS 2014).Industri ayam ras pedaging memiliki kelemahan yaitu bergantung pada pasokan bibit dan bahan baku pakan dari luar negeri sehingga tidak dapat mendukung kemandirian pangan di Indonesia (Nataamijaya 2010). Kemandirian pangan dapat dicapai melalui usaha-usaha pemuliaan dan pengembangan ternak lokal unggul. Ayam kampung merupakan salah satu ayam asli Indonesia yang memiliki potensi untuk dikembangkan sebagai bibit ayam pedaging unggul. Ayam kampung mampu beradaptasi dengan baik di lingkungan tropis (Zein dan Sulandari 2012) serta memiliki sistem imun yang kuat (Ulupi et al. 2013; Ulupi et al. 2014), namun ayam kampung memiliki kelemahan yaitu laju pertumbuhan yang lambat (Nataamijaya 2010). Laju pertumbuhan dapat ditingkatkan melalui seleksi yang terarah menggunakan penanda molekuler berbasis MAS (Marker Assissted Selection) yang terbukti dapat meningkatkan respon seleksi pada keturunan (Sartika et al. 2004).MAS dapat diperoleh melalui identifikasi gen-gen utama yang mengontrol sifat pertumbuhan pada ayam. Salah satu gen yang memegang peranan penting dalam mengontrol sifat pertumbuhan pada ayam adalah gen IGF2 (Insuline-like Growth Factor2).

Gen IGF2 pada ayam terletak di kromosom 5 terdiri dari 4 exon dan 3 intron (Ensembl nomor akses: 00000006555).Keragaman gen IGF2 diketahui berasosiasi positif dengan bobot badan dan bobot karkas umur 17 minggu pada ayam beijing you (Tang et al. 2010) serta pertambahan bobot badan (PBB) 0-6 minggu pada ayam broiler (Beccavinet al. 2001). IGF2 berfungsi sebagai promotor pertumbuhan melalui proliferasi sel dan amplifier fisiologis dari sekresi glucose-mediated insulin sehingga IGF2 berperan penting dalam menentukan perkembangan sel terutama sel tulang dan otot (Zhou et al. 1995). Penelitian ini bertujuan menganalisis hubungan keragaman gen IGF2 dengan sifat pertumbuhan pada ayam kampung.

\section{MATERI DAN METODE}

\section{Materi Ternak}

Sebanyak 56 ekor ayam kampung terdiri dari 26 ekor jantan dan 30 ekor betina dipelihara selama 16 minggu dalam kandang kelompok. Pakan yang terdiri dari campuran pakan komersil dengan dedak (60:40) dan air diberikan ad libitum.

\section{Parameter Pertumbuhan}

Parameter yang diamati yaitu laju pertumbuhan dan bobot potong. Laju pertumbuhan yang dianalisis yaitu PBB fase starter (0-8 minggu) dan PBB fase grower (9-16 minggu). Bobot potong yang dianalisis yaitu bobot potong umur 12, 14 dan 16 minggu.

\section{Aplikasi PCR (Polymerase Chain Reaction)}

DNA diisolasi dari darah ayam dan diekstraksi menggunakan metode fenol klorofom berdasarkan 
Sambrook et al. (1989). Bagian exon 4 gen IGF2 diamplifikasi menggunakan primer forward5'GCTGGGGACCCAATAGAACC-3, danreverse 5'-TCCCCAGGAGATCACAAATCG-3'. Tahapan PCR terdiri dari pre-denaturasi pada suhu $95^{\circ} \mathrm{C}$ selama 5 menit, dilanjutkan dengan 35 siklus yang terdiri dari denaturasi $95{ }^{\circ} \mathrm{C}$ selama 10 detik, amplifikasi primer $60{ }^{\circ} \mathrm{C}$ selama 20 detik dan ekstensi $72{ }^{\circ} \mathrm{C}$ selama 30 detik kemudian diakhiri pos-ekstensi pada suhu $72{ }^{\circ} \mathrm{C}$ selama 5 menit. PCR dilakukan menggunakan mesinthermocycler (Eppendor $\mathrm{f}^{\circledR}$ AG 22331). Mix PCR terdiri dari $0.3 \mu \mathrm{L}$ primer, $6.2 \mu \mathrm{L}$ DW (destilation water)dan $7.3 \mu \mathrm{L}$ GoTaq $^{\circledR}$ Green Master Mix (Promega).

\section{Genotyping Menggunakan RFLP (Restriction Fragmet Length Polymorphisms)}

Produk PCR dipotongmenggunakan enzim restriksi Nla III dengan suhu pemotongan $37{ }^{\circ} \mathrm{C}$. Mix restriksi terdiri dari $5 \mu \mathrm{L}$ produk PCR, $0.3 \mu \mathrm{L}$ enzim restriksi, $0.7 \mu \mathrm{L} 1$ $\mathrm{x}$ buffer and $1 \mu \mathrm{L}$ DW. Hasil PCR-RFLP dielektroforesis lalu divisualisasikan menggunakan UV transilluminator (AlphaImager ${ }^{\circledR}$ EP).

\section{Analisis Data Genotipe dan Fenotipe}

Frekuensi genotipe merupakan proporsi suatu genotipe relatif terhadap semua genotipe yang ada dalam suatu populasi (Noor 2010). Frekuensi genotipepada populasi ayam kampung dihitung berdasarkan Nei dan Kumar (2000) dengan rumus sebagai berikut:

$$
\mathrm{x}_{\mathrm{ii}}=\frac{\mathrm{n}_{\mathrm{H}}}{\mathrm{N}}
$$

Frekuensi alel merupakan proporsi suatu alel relatif terhadap semua alel yang ada dalam suatu populasi (Noor 2010). Frekuensi alel padapopulasi ayam kampung dihitung berdasarkan Nei dan Kumar (2000) dengan rumus sebagai berikut:

$$
x_{i}=\frac{2 n_{11}+\sum n_{i j}}{2 N}
$$

Keterangan:

$$
\begin{aligned}
& \mathrm{x}_{\mathrm{ii}}=\text { frekuensi genotipe ke- } \mathrm{ii} \\
& \mathrm{x}_{\mathrm{i}}=\text { frekuensi alel ke- } \mathrm{i} \\
& \mathrm{n}_{\mathrm{ii}}=\text { jumlah individu bergenotipe ii } \\
& \mathrm{n}_{\mathrm{ij}}=\text { jumlah individu bergenotipe } \mathrm{ij} \\
& \mathrm{N}=\text { jumlah sampel }
\end{aligned}
$$

Hubungan keragaman gen IGF2 dengan sifat pertumbuhan pada ayam kampung dianalisa dengan prosedur General Linear Model (GLM) menggunakan program SAS (SAS 9.1) dengan model sebagai berikut:

$$
\mathrm{Y}_{i j k}=\mu+\mathrm{G}_{i}+\mathrm{S}_{i}+\varepsilon_{i j k}
$$

Keterangan:

$$
\begin{aligned}
& \mathrm{Y}_{\mathrm{ijk}}=\text { parameter pertumbuhan } \\
& \mu=\text { rataan umum } \\
& \mathrm{G}_{\mathrm{i}}=\text { pengaruh genotpe ke- } \mathrm{i} \\
& \mathrm{S}_{\mathrm{j}}=\text { pengaruh jenis kelamin ke- } \mathrm{j} \\
& \mathcal{E}_{\mathrm{ijk}}=\text { pengaruh acak genotipe ke-i, jenis } \\
& \quad \text { kelamin ke-j dan ulangan ke-k }
\end{aligned}
$$

\section{HASIL DAN PEMBAHASAN \\ Penetuan Genotipe Gen IGF2 pada Ayam Kampung}

Bagian exon 4 dari gen IGF2 berhasil diamplifikasi dan menghasilkan produk PCR dengan panjang $395 \mathrm{pb}$. Beradasarkan hasil genotyping ditemukan 3 genotipe yaitu TT, TC dan CC (Gambar 1). Mutasi yang diperoleh yaitu perubahan basa timin $(\mathrm{T})$ menjadi sitosin $(\mathrm{C})$ pada basa ke138(basa ke-13161838 pada sekuen dengan nomor akses GenBank NC_006092.3). Mutasi ini merupakan mutasi transisi yaitu perubahan basa antar basa pirimidin dan bersifat synonimus karena tidak menyebabkan perubahan asam amino(Hartl dan Clark 1997). Kedua basa tersebut mengkode asam amino yang sama yaitu histidin (Amills et al. 2003).

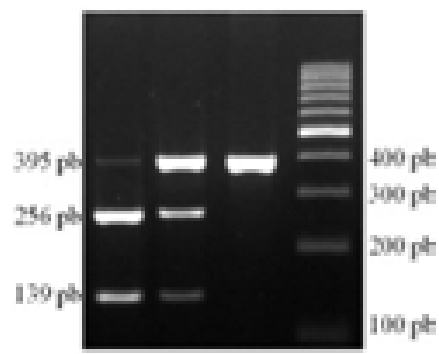

Gambar 1.Visualisasi hasil PCR-RFLP gen IGF2 pada ayam kampung. $\mathrm{M}=$ marker $100 \mathrm{pb}, \mathrm{TT} / \mathrm{TC} / \mathrm{CC}=$ genotipe individu $1-3$.

Genotipe TT dan CC disebut genotipe homozigot karena individu dengan genotipe tersebut mewarisi alel yang sama dari kedua tetuanya. Genotipe TC disebut genotipe heterozigot karena individu dengan genotipe tersebut mewarisi alel yang berbeda dari kedua tetuanya (Noor 2010).

Keragaman Gen IGF2 pada Ayam Kampung

Frekuensi genotipeTC pada ayam kampung lebih tinggi dibandingkan CC dan TC (Tabel 1). Frekuensi genotipe menunjukan peluang munculnya suatu genotip dalam populasi (Hardjosubroto 2001). Genotipe TC memiliki peluang muncul tertinggi pada populasi ayam kampung.

Suatu alel bersifat polimorfik apabila memiliki Tabel 1. Frekuensi genotipe dan alel gen IGF2

\begin{tabular}{lcccccc}
\hline \multirow{2}{*}{$\begin{array}{l}\text { Jenis } \\
\text { Ayam }\end{array}$} & \multirow{2}{*}{ N } & \multicolumn{4}{c}{ Frekuensi Genotipe } & \multicolumn{2}{c}{ Frekuensi Alel } \\
& & TT & TC & CC & T & C \\
\hline Kampung & 56 & $\begin{array}{c}0,16 \\
\text { (9) }\end{array}$ & $\begin{array}{c}0,61 \\
(34)\end{array}$ & 0,23 & 0,46 & 0,54 \\
& & $(13)$ & &
\end{tabular}

frekuensi alel kurang dari 0.99 (Hartl dan Clark 1997). Frekuensi alel $\mathrm{C}$ ditemukan lebih tinggi daripada alel $\mathrm{T}$, namun frekuensi keduanya kurang dari 0.99 sehingga gen IGF2 pada populasi ayam kampung yang dianalisa bersifat polimorfik. Sifat polimorfik merupakan salah satu syarat agar sutau gen dapat dijadikan gen kandidat untuk sifat tertentu (Hartl dan Clark 1997).

Hubungan Keragaman Gen IGF2 terhadap Sifat Pertumbuhan Ayam Kampung

Parameter yang diamati pada penelitian yaitu PBB fase starter sebagai selisih bobot badan umur 8 dengan 0 minggu, PBB fase grower sebagai selisih bobot badan umur 16 dengan 9 minggu serta bobot potong umur 12, 14 dan 16 minggu. Hasil penelitian menunjukkan tidak ditemukan hubungan antara keragaman gen IGF2 dengan sifat pertumbuhan pada ayam kampung (Tabel 2). Hasil 
Tabel 2. Asosiasi gen IGF2 terhadap pertumbuhan ayam kampung

\begin{tabular}{lrrr}
\hline \multirow{2}{*}{ Parameter } & \multicolumn{3}{c}{ Genotipe } \\
\cline { 2 - 4 } & \multicolumn{1}{c}{ TT } & TC & CC \\
\hline PBB 0-8 mg (g/8 mg) & $446,63 \pm 32,09$ & $424,89 \pm 16,36$ & $434,71 \pm 26,48$ \\
PBB 9-16 mg (g/8 mg) & $536,82 \pm 50,55$ & $524,26 \pm 25,77$ & $494,49 \pm 41,71$ \\
BB 12 mg (g) & $742,34 \pm 47,72$ & $718,34 \pm 24,33$ & $740,17 \pm 39,38$ \\
BB 14 mg (g) & $808,94 \pm 60,36$ & $833,23 \pm 30,78$ & $827,96 \pm 49,80$ \\
BB 16 mg (g) & $1116,74 \pm 71,81$ & $1099,12 \pm 36,62$ & $1078,73 \pm 59,26$ \\
\hline
\end{tabular}

Keterangan: PBB (Pertambahan Bobot Badan), BB (Bobot Badan)

ini sejalan dengan Amills et al. (2003) yang melaporkan tidak ditemukan pengaruh keragaman gen IGF2 terhadap performa pertumbuhan ayam black penedesenca meskipun terdapat perbedaan konsentrasi plasma IGF2 pada genotipe yang berbeda.

Tidak adanya asosiasi antara keragaman gen IGF2 dengan sifat pertumbuhan pada ayam kampung kemungkinan disebabkan oleh beberapa faktor yaitu jenis mutasi yang terjadi dan faktor internal dari tubuh ayam. Mutasi yang terjadi yaitu mutasi basa timin (T) menjadi sitosin (C). Menurut Amills et al. (2003) yang melakukan penelitian pada ayam black penedesenca, mutasi tersebut merupakan mutasi synonimus yang mengkode asam amino yang sama yaitu histidin sehingga tidak memberikan pengaruh terhadap performa ayam.

Fenomena lain yang mungkin terjadi yaitu adanya pengalihan energi pada tubuh ayam kampung. Hal ini sesuai dengan Despal et al. (2007) yang mengemukakan bahwa terdapat pengalihan energi pada tubuh ternak jika ternak harus bertahan hidup pada lingkungan yang ekstrim. Energi dalam tubuh digunakan utamanya untuk kehidupan pokok lalu untuk produksi dan reproduksi. Jika energi terlalu banyak digunakan untuk hidup pokok maka akan terjadi pengalihan penggunaan energi sehingga energi untuk kebutuhan produksi akan berkurang. Hal ini mungkin terjadi pada ayam kampung yang hidup di lingkungan tropis dan terpapar banyak agen penyakit. Adanya interaksi genetik dan lingkungan dapat menyebabkan suatu gen aktif pada kondisi tertentu dan tidak aktif pada kondisi lainnya (Falconer dan Mackay 1996). Untuk memperoleh performa yang optimal, sebaiknya ayam kampung dipelihara di lingkungan yang nyaman (comfort zone) sehingga energi untuk hidup pokok dapat diminimalisir dan energi untuk produksi dapat ditingkatkan.

\section{KESIMPULAN}

Gen IGF2 pada ayam kampung bersifat polimorfik. Genotipe TC memiliki frekuensi tertinggi dibandingkan genotipe lainnya. Tidak ditemukan hubungan antara keragaman gen IGF2 dengan sifat pertumbuhan pada ayam kampung.

\section{DAFTAR PUSTAKA}

Amills, M., N. Jimenez, D. Villalba, M. Tor, E. Molina, D. Cubilo, C. Marcos, Francesch, A. Sanchez, \& J. Estany.2003.Identification of three single nucleotide polymorphisms in the chicken insuline-like growth factor 1 and 2 genes and their associations with growth and feeding traits. Poultry Sci.82:1485-1493.
Badan Pusat Statistik.2014.Statistik Indonesia.Badan Pusat Statistik Indonesia, Jakarta.

Beccavin, C., B. Chevalier, L. A. Cogburn, J. Simon, \& M. J. Duclos. 2001. Insulin-like growth factors and body growth in chickens divergently selected for high or low growth rate. J Endocrinol. 168:297-306.

Despal, D. A. Astuti, D. M. Suci, D. Evvyerni, I. G. Permana, N. E. Sigit, R. Mutia, Sumiati, T. Tohormat, \& W. Hermana.2007.Pengantar Ilmu Nutrisi. Dept. Ilmu Nutrisi dan Teknologi Pakan IPB, Bogor.

Falconer, D. S., \& T. F. C. Mackay.1996. Quantitative Genetics. $4^{\text {th }}$ ed. Longman Group Ltd, Edinburgh.

Hardjosubroto, W. 2001.Genetika Hewan. Universitas Gadjah Mada Press, Yoygyakarta.

Hartl, D. L., \& A. G. Clark.1997.Principles of Population Genetics. $3^{\text {rd }}$ ed. Sinauer Associate Inc, Sunderland.

Nataamijaya, A. G. 2010. Pengembangan potensi ayam lokal untuk menunjang peningkatan kesejahteraan petani. J Litbang Pertanian. 29:131-138.

Nei, M., \& S. Kumar. 2000.Molecular Evolution and Phylogenetics. Oxford Univ Press, New York.

Noor, R. R. 2010. Genetika Ternak. Penebar Swadaya, Jakarta.

Sambrook, J., E. F. Fritsch, \& T. Maniatis. 1989. Molecular Cloning: A Laboratory Manual. CSH Laboratory Press, USA.

Sartika, T., S. Iskandar, L. H. Prasetyo, H. Takahashi, \& M. Mitsuru. 2004. Kekerabatan genetik ayam kampung, pelung, sentul dan kedu hitam dengan menggunakan penanda DNA mikrosatelit: I. Grup pemetaan pada makro kromosom. JITV. 9:81-86.

Tang, S., D. Sun, J. Ou, Y. Zhang, \& G. Xu. 2010. Evaluation of the IGFs (IGF1 and IGF2) genes as candidates for growth, body measurement, carcass, and reproduction traits in beijing you and silkie chickens. Animal Biotech. 21:2.

Ulupi, N., Muladno, C. Sumantri, \& I. W. T. Wibawan. 2013. Association of TLR4 gene genotype and resistance against Salmonella enteritidisnatural infection in kampung chicken. IJPS. 12:445-450.

Ulupi, N, Muladno, C. Sumantri, \& I. W. T. Wibawan. 2014.Study of kampung chicken resistance against Salmonella enteritidis using TLR4 gene as marker. IJPS. 13:467-472.

Zein, M. S. A., \& S. Sulandari. 2012. Keragaman genetik dan distribusi haplogrup ayam kampung dengan menggunakan hipervariabel-I daerah kontrol DNA mitokondria. JITV. 17:120-131.

Zhou, M., Z. Ma, \& W. S. Sly. 1995. Cloning and expression of the cDNA of chicken cation independent mannose-6-phosphate receptor. Proc Natl Acad Sci. 92:9762-9766. 